\title{
How did the U.S. stock market recover from the Covid-19 contagion?
}

\author{
Shyam Sunder ${ }^{1}$
}

Received: 19 June 2020 / Accepted: 22 June 2020 / Published online: 6 July 2020

(c) Springer-Verlag GmbH Germany, part of Springer Nature 2020

Lockdowns in many economies around the world since March, and a sharp rise in U.S. unemployment, prompted a $30 \%$ drop in stock prices. However, the U.S. stock price rebound in the first half of June 2020, in spite of economic projections of sharply lower, perhaps negative economic growth and business profits for 2020, surprised many. If the price of a company's shares reflects the discounted present value of future cash flows to shareholders, this stock market recovery makes little sense. However, there is a second important determinant of stock prices-the amount of money made available in the hands of investors by central banks.

In recent decades, central banks have reacted to sharp stock market declines by pumping money into the economy through "quantitative easing" (QE) programs to buy government and corporate debt. The size of assets on central bank balance sheets is a measure illustrating this. See Fig. 1 for a time series of total consolidated assets on the U.S. Federal Reserve System (FRS) balance sheet from December 2002 to June 2020. In 2008, the FRS assets more than doubled from US\$901,710 million on August 6, 2008, to US\$2,212,852 million on November 12, 2008. As the risk of widespread bankruptcies in the financial sector subsided, the stock market responded to this massive injection of money in the following year by recovering a large part of its losses and rising well above the 2008 levels.

The COVID-19 pandemic also induced an economic panic in March 2020. The FRS responded to the panic by again expanding its balance sheet assets by $66 \%$, from US\$4,241,507 million on March 4, 2020, to US\$7,037,258 million on May 20, 2020: not surprisingly, the stock market soon recovered most of its March-April 2020 losses during May-June 2020.

Shyam Sunder is the James L. Frank Professor of Accounting, Economics, and Finance at the Yale School of Management and Professor (by courtesy) in the Department of Economics. He will be inducted into the Accounting Hall of Fame at the annual American Accounting Association (AAA) meeting in August 2020.

Shyam Sunder

shyam.sunder@yale.edu

1 Yale University, New Haven, USA 


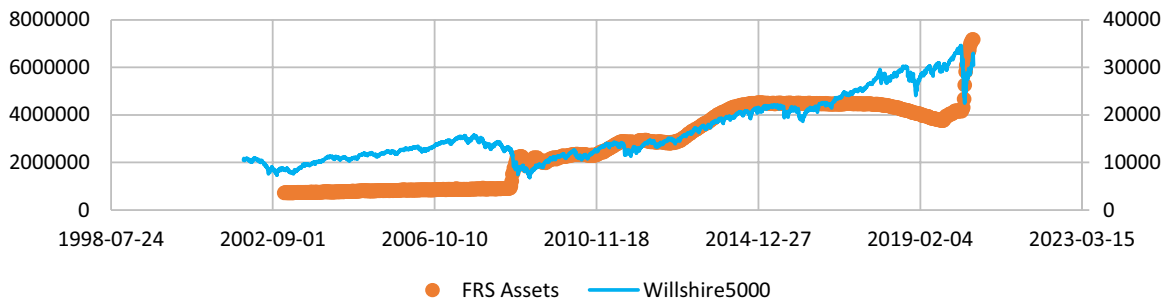

Fig. 1 US FRS assets and Wilshire 5000 stock price index. Data: https://fred.stlouisfed.org/

The FRS has responded to sharp drops in stock prices during the recent two decades by pumping massive amounts of liquidity into the economy. These interventions to induce a price recovery have created a not-so-unreasonable expectation that any future precipitous stock price declines may also elicit a similar response from the central bank, especially during an election year under heavy political pressure. If rising stock prices are considered normal by investors and policymakers, and the latter tend to intervene to engineer a recovery from sharp declines, it does not seem unreasonable to believe (as some do) that the stock market will always go up. This expectation of policy has earned its own moniker of "central bank put".

In addition to the data from the field, a recent experimental research study (Hirota et al. 2020, forthcoming in $J E B O$ ) finds strong evidence that, even in the absence of any doubts about the fundamental value of securities, the presence of more money in the hands of investors generates higher prices in laboratory markets. Figure 2 summarizes the average price data during 16 periods of six low- and six high-liquidity independent sessions that involved a total of 180 human subjects.

The study concludes that the correspondence between prices and fundamental values in security markets requires not only that the investors be rational, but also that they expect the other current and future investors to behave rationally. While the first assumption may hold true, the second one is unlikely to hold true. Even in a world of rational investors, not everyone believes that all others are and will

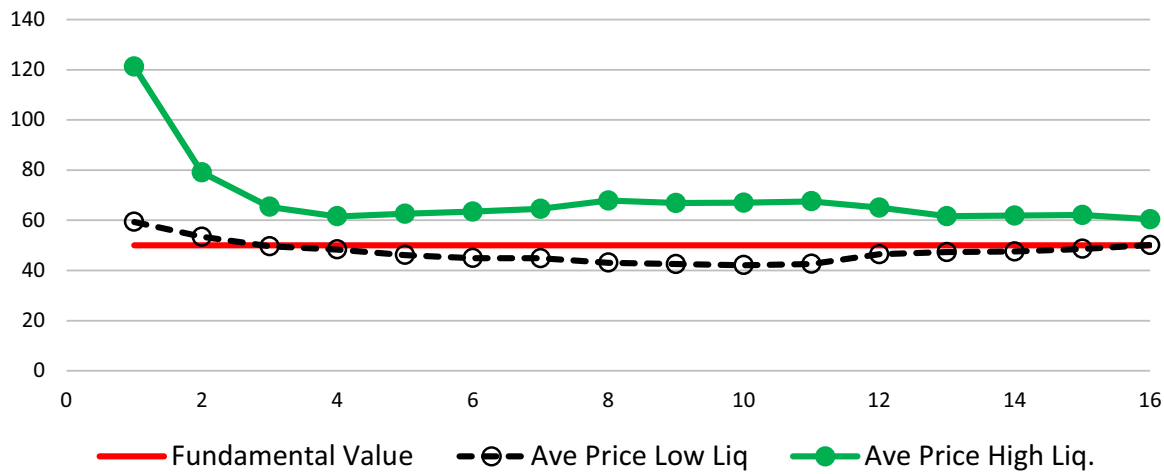

Fig. 2 Price levels under low and high liquidity. Source: Hirota et al. (2020) 
be rational; i.e., belief in the rationality of other investor is unlikely to be common knowledge in the investor community.

In such a world, it should not be a surprise that changes in money supply affect stock prices. Perhaps this helps explain the rise in stock prices in recent months as a response to greatly increased liquidity injected by decisions of the U.S. Federal Reserve.

During the 2008 financial crisis, the QE policies of the U.S. and other developed economies also appeared in the actions of central banks of South Korea and Israel. In 2020, several other developing economies-Hungary, Indonesia, Malaysia, the Philippines, Poland, South Africa, and Turkey - have joined Israel and South Korea with QE programs of their own with varied sizes and goals. The effectiveness of pursuing such policies in the absence of reserve currency status remains uncertain.

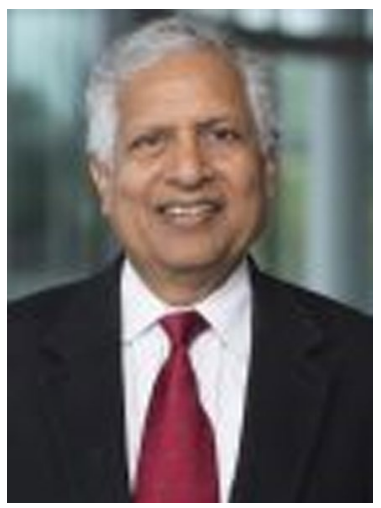

Shyam Sunder

James L. Frank Professor of Accounting, Economics, and Finance

\section{Reference}

Hirota S, Huber J, Stoeckl T, Sunder S (2020) Speculation and price indeterminacy in financial markets: an experimental study. Cowles Foundation discussion paper 2134R. J Econ Behav Organ (forthcoming). https://cowles.yale.edu/sites/default/files/files/pub/d21/d2134-r.pdf

Publisher's Note Springer Nature remains neutral with regard to jurisdictional claims in published maps and institutional affiliations. 